\title{
Excess Plutonium Disposition Using ALWR Technology (U)
}

M. R. Buckner

J. A. Radder

J. G. Angelos

H. Inhaber 


\section{Approvals}

A Beranele by Obais F. Beranek, Manager Nuclear Reactor Technology and Scientific Computations

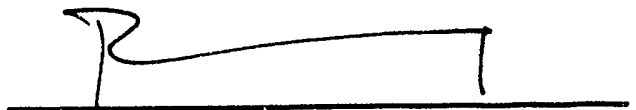

R. E. Seif, Manager

Transition and Reconfiguration

Program Integration

M. R. Buckner, Manager

Scientific Computations

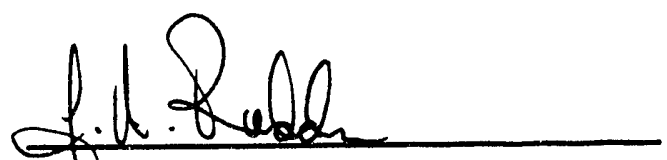

J. A. Radder, Sr. Fellow Scientist

Safety Technology

\section{C.M. Angelos}

J. G. Angelos, Manager

Transition and Reconfiguration

Program Integration

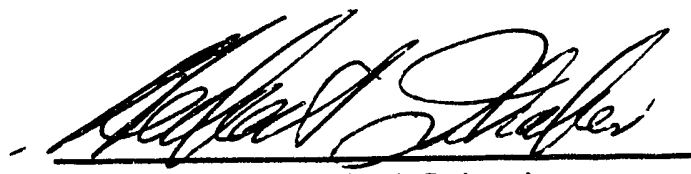

H. Inhaber, Principal Scientist Safety Technology
$12-21-92$

Date

$12 / 15 / 92$

Date

$12-10-92$

Date

$12-10-92$

Date

12- $14-92$

Date

$$
12-15-92
$$

Date 


\section{Introduction and Summary}

The Office of Nuclear Energy of the Department of Encrgy chartered the Plutonium Disposition Task Force in August 1992. The Task Force was created to assess the range of practicable means of disposition of excess weapons-grade plutonium. Within the Task Force, working groups were formed to consider: (1) storage, (2) disposal, and (3) fission options for this disposition, and a scparate group to evaluate nonproliferation concerns of cach of the alternatives. As a member of the Fission Working Group, the Savannah River Technology Center acted as a sponsor for light water reactor (LWR) tcchnology. The information contained in this report details the submittal that was made to the Fission Working Group of the technical assessment of LWR technology for plutonium disposition. The following aspects were considered: (1) proliferation issues, (2) technical feasibility, (3) technical availability, (4) economics, (5) regulatory issucs, and (6) political acceptance.

LWR technology is a safe and viable option for the disposition of wcapons-grade plutonium by fission. The technology is mature and considerable effort has been invested in enhanced designs that include advanced safety features. Plutonium from commercial spent fucl has becn successfully recycled in LWRs as a mixed oxide (MOX) fucl since the mid-1960s, and fabrication processes are quite similar to those used by the commercial industry. Nevertheless, both the utility industry and the public will need to be convinced by a demonstration that the use of such fucls in an LWR is feasible. An advanced light water reactor (ALWR), partly fucled by weaponsgrade plutonium, is proposed to demonstrate this concept at a government-controlled facility. Such a demonstration would serve the dual purpose of producing electrical power and, simultancously, denaturing plutonium to prevent its re-use in nuclear weapons. Spent plutoniumbased fucl from an ALWR may be treated in much the same manncr as is planned for uranium-based, commercial fucl. The concept is shown schematically in Figure 1.

The new generation of ALWRs includes passive design plants in the 600-MWe range and evolutionary design plants in the 1200 -MWe range. Either plant design can be a pressurized water reactor or boiling water reactor, depending on the reactor vendor. An ALWR provides several valuable side benefits to the nuclear industry. These benefits are

- input to the design certification process for NRC approval of new nuclear power plant designs
- use of the NRC's proposed one-step licensing process for new power plant construction and operation

At the present time, the reactor vendors are secking NRC Final Design Approval for their respective ALWR plant designs. A government-sponsored ALWR would accelcrate the process of certifying and building the next generation of nuclear power plants. Whilc this concept represents an enhancement of existing technology, it is firmly grounded on the established nuclear industry base of 110 opcrating reactors with over 1200 years combined experience.

Considerable effort has been expended to optimize advanced LWR designs. A high reliability factor can be placed in the estimated costs and schedule that follow. Initial capital and annual operating costs for a demonstration system (MOX fucl fabrication plant and a single 600-MWe ALWR assumed) are estimated to be approximately $\$ 1.5$ to $\$ 2$ billion and $\$ 110$ million/ycar, respectively. The capital and operating costs for a complete energy park (MOX fucl fabrication plant and three 600-MWe ALWRs assumed) are estimated to be approximately $\$ 4$ to $\$ 4.5$ billion and $\$ 250$ million/year, respectively. The value of electricity produced would be about $\$ 300$ million per year for the demonstration system and $\$ 900$ million per year for the energy park scheme.

The demonstration system, which is assumed to consist of a MOX fucl fabrication plant and a single $600-\mathrm{MWe}$ ALWR, would be constructed on a 6-to 8-year schedulc. Additional ALWR units would be constructed, or existing utility LWRs would be licensed, to use MOX fucl about 4 ycars after initial operation of the demonstration system. This schedule would provide adequate time for demonstrating the plutonium fuel cycle and for defining and providing appropriate safcguards to allow utility usc of weapons-based MOX fuel. With the range of benefits for the nuclear and defense industries under this concept, it appears highly fcasible that a joint funding arrangement between the private (vendors and utilitics) and government (DOE and NRC) sectors could be developed. Based on thesc considerations, the above concept provides a reliable and cost-effective option for denaturing the excess weapons-grade plutonium stockpilc.

The New Production Reactor (NPR), which is currently proposed to be either a low-temperature heavy-water reactor (LTHWR) or a modular high-temperature gascooled reactor (MHTGR), could also be designed for a plutonium fucl cycle. Both reactor designs are well developed and have been sclected through a long cvaluation process as prime candidates for new production capability. The LTHWR relies on the proven tritium 


\section{Plutonium Disposition Via LWR Technology}

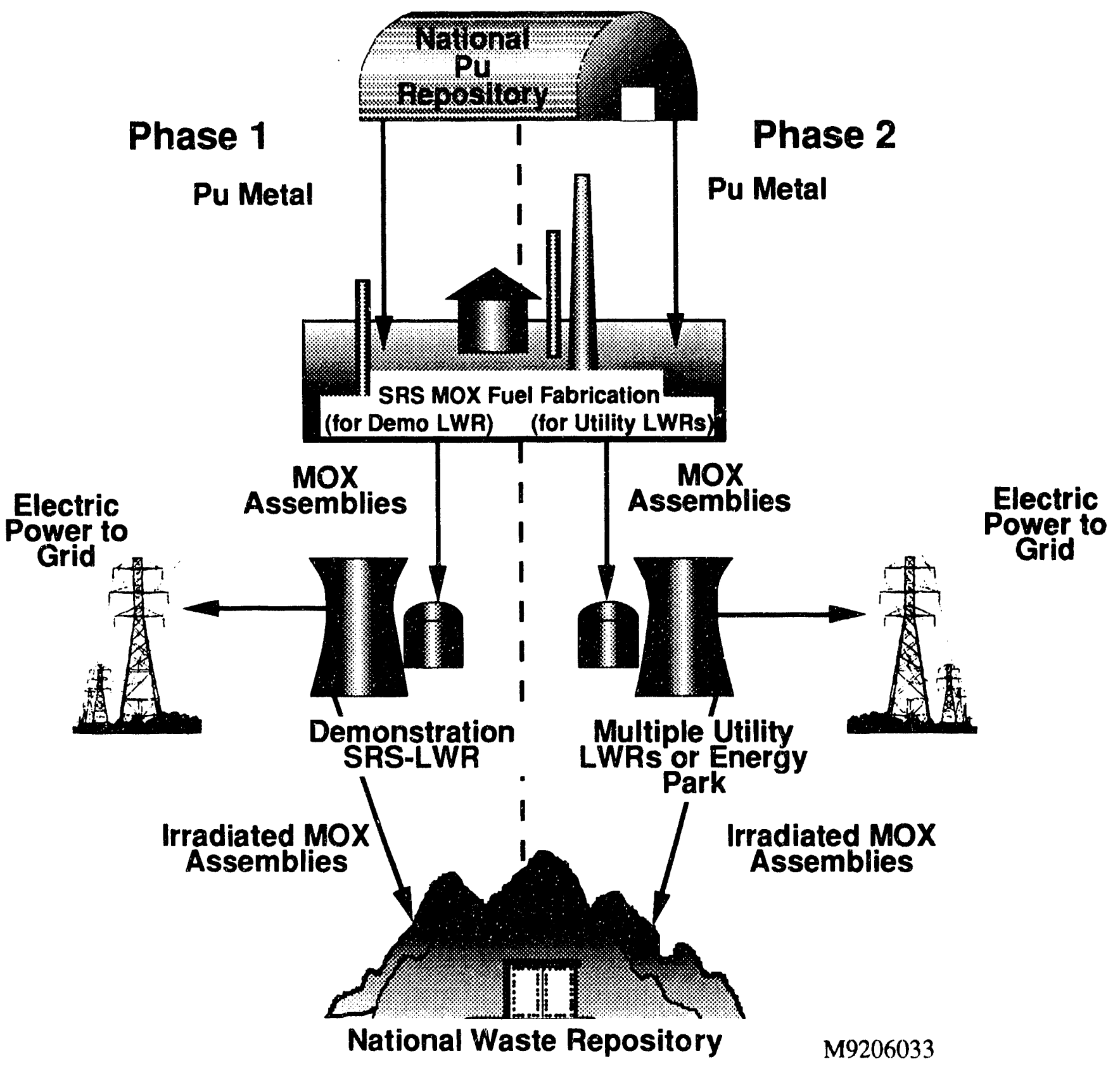

Figure 1. Plutonium Disposition via LWR Technology 
production capacity of the Savannah River Site (SRS) reactors. The MHTGR has the capacity to demonstrate advanced gas-cooled technology as well as produce significant amounts of tritium. However, an ALWR might also provide the option of producing tritium as required to support defense programs. Tritium production in LWRs has been demonstrated and, with further development of this technology to production status, an ALWR could provide a future production source, reducing the need for additional production facilities. The benefit/cost ratio would be even greater than estimated here if this option were adopted.

The leader of the Fission Working Group also requested that DOE sites be compared to evaluate their potential for locating facilities required for plutonium disposition. This evaluation was reviewed and enhanced by the Fission Working Group at the Group Review Meeting (DOE-Germantown) on September 16, 1992. The results of this evaluation are presented here for information.

Because of proliferation concerns, any option chosen for plutonium disposition should be on a government site. The location chosen to demonstrate the fission option should have considerable plutonium experience and a dedicated infrastructure that can support all phases of the fuel cycle. Morcover, it should be controlled, to eliminate any proliferation concerns with respect to weapons-grade plutonium handling. Table 1 presents a comparison of the possible DOE sites based on factors important to implementation of the fission option.

\begin{tabular}{|c|c|c|c|c|c|c|}
\hline Attribute & SRS & INEL & Hanford & Pantex & Nevada Test & Oak Ridge \\
\hline $\begin{array}{l}\text { Controlled } \\
\text { Site }\end{array}$ & $X$ & $X$ & $X$ & $X$ & $X$ & $X$ \\
\hline $\begin{array}{l}\text { Established } \\
\text { Infrastructure }\end{array}$ & $x$ & $\mathrm{X}$ & $X$ & & & $X$ \\
\hline $\begin{array}{l}\text { Plutonium } \\
\text { Handling }\end{array}$ & $\mathrm{X}$ & $\mathrm{X}$ & $X^{*}$ & $X$ & & \\
\hline $\begin{array}{l}\text { Plutonium } \\
\text { Processing }\end{array}$ & $X$ & & $\mathrm{X}^{*}$ & & & \\
\hline $\begin{array}{l}\text { Reprocessing } \\
\text { Capability }\end{array}$ & $X$ & $\mathrm{X}^{* *}$ & $X^{*}$ & & & \\
\hline $\begin{array}{l}\text { Waste Handling } \\
\text { Facilitics }\end{array}$ & $\mathrm{X}$ & $X$ & $\mathrm{X}$ & & & \\
\hline $\begin{array}{l}\text { Tritium } \\
\text { Facilitics }\end{array}$ & $\mathrm{x}$ & & & & & \\
\hline $\begin{array}{l}\text { Reactor } \\
\text { Experience }\end{array}$ & $X$ & $X$ & $X$ & & & $\mathrm{X}$ \\
\hline $\begin{array}{l}\text { Reactor } \\
\text { Support Facilities }\end{array}$ & $X$ & $X$ & $X$ & & & \\
\hline $\begin{array}{l}\text { Above U.S. } \\
\text { Avcrage Load } \\
\text { Growth }\end{array}$ & $X$ & & & $X$ & & $x$ \\
\hline $\begin{array}{r}{ }^{*} \text { Currently not ava } \\
\text { *** Enriched uraniu }^{*} \text { "Plutoniun } \\
\text { and "Pluto } \\
\text { chemical o }\end{array}$ & $\begin{array}{l}\text { at } \mathrm{Ha} \\
\text { rocess } \\
\text { dling" } \\
\text { Proce } \\
\text { r mea }\end{array}$ & $\begin{array}{l}\text { acilitic: } \\
\text { handlin } \\
\text { eans } \mathrm{ct}\end{array}$ & $\begin{array}{l}\text { ed) } \\
\text { tonium o } \\
\text { ng the ste }\end{array}$ & $\begin{array}{l}\text { ium-bas } \\
\text { utonium }\end{array}$ & $\begin{array}{l}\text { terial without } \\
\text { tonium-basec }\end{array}$ & $\begin{array}{l}\text { ng its state } \\
\text { ial through }\end{array}$ \\
\hline
\end{tabular}




\section{Technical Assessment-Description of ALWR}

The ALWR is envisioned to be either a passive design plant in the 600 -MWe range or an evolutionary design plant in the $1200-\mathrm{MWe}$ range.

The passive plant uses simple safety systems that are essentially non-active. This is the so-called "walk-away safe" design that does not require operator action for an indefinite period of time following an accident. Some of the support systems for safety systems that are active in conventional and evolutionary plants can be installed and maintained as non-safety related in the passive plant. Examples of such systems include cooling water, HVAC, AC power, and diesel generators. Passive ALWRs are designed to generate power in the $600-\mathrm{MWe}$ range.

The evolutionary plant uses active safety systems to mitigate accidents. Although these systems are similar to those in conventional plants, they have additional built-in redundancy and diversity. The evolutionary plant addresses the "walk-away safe" concept by using digital, software-driven instrumentation and controls to eliminate the need for operator action for an indefinite time following an accident. Hard-wired, analog controls are provided as a backup to allow operators to intervene in the event of computer malfunction. Evolutionary plants have been projected for the 1200-MWe range.

Even though the passive and evolutionary ALWRs approach plant safety from different perspectives, as noted earlier, the basic plant designs share many similarities. Each ALWR design type is based on having a standard plant design for a particular family (e.g., passive 600-MWe PWR) and both ALWR design types have many functionally identical structures and equipment. A brief description of some of the major structures and equipment that fall into this category are noted below:

- full-size, zero-leakage, reactor containment buildings

- reactor plant equipment including reactor vessel, steam generators (PWR only), reactor coolant/recirculation pumps, valves, and associated piping

- auxiliary/reactor buildings

- engineered safeguards equipment for reactor inventory control, decay heat removal, and containment heat removal

- diesel generators for onsite power supply

- turbine buildings

- turbine plant equipment including turbine/generator main condenser, and main feedwater and condensate systems

- main and auxiliary electrical switchyards

- $\mathrm{AC}$ and DC plant electrical systems

- cooling towers and associated water handling systems

- fire protection systems

- auxiliary boilers

- storage tanks for condensate and reactor water

- fuel handling and radioactive waste systems 


\section{Proliferation Issues}

Many issues of proliferation will be solved by this proposal. The points made here are applicable to many of the plutonium dispositioning fission options including liquid metal and gas-cooled reactors as well as the ALWR. The first part will deal with strengths of the ALWR concept in terms of non-proliferation. The second part will deal with more general questions applicable to most fission options.

\section{I - Aspects Applicable to ALWR}

(1) The question of verifiability is key in any proliferation discussion. From that aspect the ALWR is strong. It will be possible to verify the handling of the plutonium and its denaturing at all stages of the process by means of physical measurements. These measurements can be subjected to any desired degree of reproducibility.

(2) Any process designed to prevent proliferation must be irreversible. That is, any residual plutonium or other matcrials that can be used to make weapons must be extremely difficult, if not impossible, to produce after the original plutonium is denatured.

The ALWR offers almost complete irreversibility. The actinides resulting from the plutonium denaturing would be extremely difficult to collect to use in weapons. Only the highest-level effort, comparable to building nuclear weapons from a zero base, could achieve this. In that sense, then, the ALWR process is irreversible. A complete listing of actinide levels as a function of time-in-reactor and applicability to weapons processes is available.

\section{II - General Aspects of Non-Proliferation}

(1) Human history shows many examples of how an administrative solution cannot solve long-term problems with a strong degrec of certainty. Some examples are the tombs of royalty in ancient Egypt and the Yucatan Peninsula of present-day Mexico. The administrative "solution" of declaring them to be holy and off-limits did not prevent subsequent looting over the centuries.

Mcrely storing excess plutonium in a building or facility, no matter how strong the locks or how high the fence, will not "solve" the problem in the ordinary sense. This is intuitively obvious to both the general public and policy-makers. The only real solution to the excess plutonium is to make it much more inaccessible to those who would re-use it for weapons by means of a technical approach (i.e., denaturing it in a reactor).

(2) While the political leadership of the Commonwealth of Independent States (CIS) has expressed confidence in U.S. solutions to proliferation, significant elements in that region place little credence in U.S. intentions. The elements include senior members of the military and some opposition members in the Russian legislature. They have been publicly quoted as suggesting that, unless the U.S. disposes of its weapons material in a public and demonstrable way, the effect of Russian disarmament would be to give the U.S. a dominant position over that nation.

(3) Even if full agreement was reached between the U.S. and the CIS on proliferation questions, other nations, both weapons states and others, would want to be reassured on this vital point. If the U.S. could demonstrate that the plutonium removed from weapons had been denatured and could not be used for weapons without substantial effort, world-wide non-proliferation, as contrasted to that between the U.S. and the CIS, would be enhanced.

(4) The system could lead to other confidence-building measures between the U.S. and the CIS. Assuming that the ALWR was built, observers from the CIS could be stationed at the plant's location, to ensure that the plutonium was being used as specified in the agreement between the two nations. This action would build much more mutual confidence than a mere statement by the U.S. that the plutonium had been dispositioned.

(5) From a commercial viewpoint, stationing CIS observers at the proposed plant would give them more familiarity with U.S. technology. Former President Bush and other leaders of the G-7 have announced that a major goal of world nuclear policy is to improve reactor safety in Russian reactors. Implementation of this proposal would help to achicve this goal. Additionally, this step would, in the long run, give the Russian nuclear industry much more exposure to U.S. safety systems and measures. This could then lead to trade in services and supplies in this area between the two nations. 


\section{Technical Feasibility}

Plutonium has becn successfully used as a power source in LWR mixed-oxide (MOX) fuel over the past several decades. Beginning in 1963, Belgium used increasing amounts of MOX fucl in the BR3 PWR, achieving a proportion of $70 \%$ MOX fuel after the 1986 refueling. Commercial MOX utilization in the Federal Republic of Germany started in 1981, after a demonstration period from 1968 to 1977. Switzerland began steadily loading MOX fucl into Beznau in 1984, and Electricité de France decided to load MOX on a commercial basis in 16 plants during 1985. Japan launched a small scale MOX demonstration program at Tsuruga 1 and Mihama 1 in 1986 and now plans to use MOX fucl at 12 plants in the $1000-\mathrm{MW}$ range by 1997 . The United States also played a significant role in developing and demonstrating MOX fucl. Specifically, Westinghouse provided the design, safety analysis, and fabrication of MOX fuel for the Saxton, San Onofre 1, Bcznau 1, Mihama 1, and Trino nuclear power plants.

One of the most cost-effective ways to denature weapons-grade plutonium is to convert it to a MOX fuel for use in an clectricity-producing power reactor. Weaponsgrade plutonium can be converted to $\mathrm{PuO}_{2}$ powder (by an existing dissolution process), blended with depleted $\mathrm{UO}_{2}$ powder, and pressed into MOX fuel pellets. Once the pellet stage is reached, the remaining steps of the process are identical to those used in the fabrication process for commercial fucl. Historically, MOX fuel incorporated in LWR cores has bchaved outstandingly well, usually better than the uranium fucl that was also present. ${ }^{1}$ By using MOX fucl and opcrating at $80 \%$ availability, a 600-MWe commercial LWR would produce electricity that has an annual value approaching $\$ 280$ million per year. This estimate is based on a U.S. average end-use price (including residential, industrial and commercial applications) of $6.7 \notin / \mathrm{kWh}$ (1990 dollars). ${ }^{2}$ This is the gross revenue expected and does not account for clectrical production costs.

The U.S. nuclear industry has reached a level of maturity that makes LWR technology a strong option to disposition plutonium. As of 1991, there were 110 operating LWR plants in the U.S. with a collective experience excecding 1200 years of reactor operation. The Institute of Nuclear Power Operations (INPO) collects data from these plants and converts it into performance indicators that are used to measure margin of safety and overall excellence in LWR operations. Industry progress over the past decade, as measured by these indicators, is significant ${ }^{3}$ as can be seen in Table 2 . In addition to performance indicators, probabilistic risk assessment
(PRA) methods are used to cvaluate plant vulnerabilities associated with severe accidents. Currently, cach nuclear plant in the U.S. is in the process of performing such an cvaluation through the Individual Plant Examination Program. Insights from these cvaluations are used as the basis for making plant design changes that improve safety and lower the overall plant risk profile.

Building on this extensive experience base from threc decades of LWR operations, the U.S. nuclear industry is finishing designs for a new generation of advanced lightwater reactors (ALWRs). The ALWR concept is proposed as a safe and viable option to disposition weaponsgrade plutonium through the fission process. The ALWR generation of plants includes both pressurized-water reactor (PWR) and boiling-water reactor (BWR) plants, cither of which can be passive or cvolutionary in terms of design. The ALWR system allows for a lengthy time interval between the time that a non-standard condition is detected and when operator intervention is required (i.c., it is "walk-away safe").

The passive ALWR safety systems rely on the dependable forces of gravity, natural circulation, and cooling by convection and evaporation to protect the reactor in the unlikely event of an accident. Safety injection, residual heat removal, containment spray, and containment cooling perform automatically if they are ever required. These systems are technically described as "passive" because no active or external power sources are required for the successful operation of the systems.

The evolutionary ALWR uses active safety systems for accident mitigation. These systems have evolved from the engineered safety features found in present-day LWRs. The systems offer such improvements as additional built-in redundancy and diversity. The cvolutionary plant addresses the "walk away safe" concept by using digital, softwarc-driven instrumentation and controls to preclude opcrator action for an indefinite time following an accident. Hard-wired, analog controls are provided as a backup to allow operators to intervene in the event of computer malfunction.

To discuss how an ALWR can be used to demonstrate the safe denaturing of plutonium by fission, it is assumed that a passive 600-MWe ALWR plant would be built and operated at a government-controlled facility. Furthermore, it is assumed that the demonstration plant will be a PWR (i.c., Westinghouse AP-600) because more detailed information is available for this plant than any of the other ALWRs. However, most of the general information should also be applicable to Ciencral Electric's $6(0)-M W c$ Simplificd BWR (SBWR) plant. 
Table 2. Unit Average Performance Indicators for the Nuclear Industry

\begin{tabular}{|c|c|c|c|}
\hline Performance Indicator & 1980 & $\frac{\text { Ycar }}{1985}$ & 1990 \\
\hline 1. Equivalent Availability Factor & $59.8 \%$ & $63.5 \%$ & $68.4 \%$ \\
\hline 2. Unplanned Automatic Scrams & $7.4 / \mathrm{yr}$ & $4.3 / \mathrm{yr}$ & $1.6 / \mathrm{yr}$ \\
\hline 3. Unplanned Safety System Actuations & $\mathrm{N} / \mathrm{A}$ & $1.3 / \mathrm{yr}$ & $0.7 / y r$ \\
\hline $\begin{array}{l}\text { 4. Collective Radiation Exposure } \\
\text { - BWR Units (man-rem) } \\
\text { - PWR Units (man-rem) }\end{array}$ & $\begin{array}{r}1,230 / \mathrm{yr} \\
597 / \mathrm{yr}\end{array}$ & $\begin{array}{l}800 / \mathrm{yr} \\
425 / \mathrm{yr}\end{array}$ & $\begin{array}{l}436 / \mathrm{yr} \\
294 / \mathrm{yr}\end{array}$ \\
\hline $\begin{array}{l}\text { 5. Lost-Time Accident Rate } \\
\text { (number per } 100 \text { man-years worked) }\end{array}$ & 1.36 & 0.64 & 0.22 \\
\hline $\begin{array}{l}\text { 6. Low-Level Solid Rad Waste } \\
\text { - BWR Units (cubic meters/yr) } \\
\text { - PWR Units (cubic metcrs/yr) }\end{array}$ & $\begin{array}{r}1,113 \\
586\end{array}$ & $\begin{array}{l}797 \\
334\end{array}$ & $\begin{array}{l}301 \\
108\end{array}$ \\
\hline
\end{tabular}

1. Equivalent availability factor is the ratio of the total power a unit could produce, considering equipment and regulatory limits, to its rated capacity. At least 30 nuclear units had availability factors above $76 \%$ in 1990 compared to only 13 in 1985 . (All 6 Westinghousc 2-loop plants had an average availability of $86 \%$.)

2. Unplanned automatic scrams are those that occurred due to equipment failures or human errors. Fewer scrams mean less challenges to safety and balance of plant systems.

3. Unplanned safety system actuations include unplanned emergency core cooling system and cmergency $\mathrm{AC}$ power system actuations. Fewer actuations indicate greater care in plant operation, which contributes to a higher margin of safety.

4. Collective radiation exposure is the total exposure that plant workers received during the year. Low exposure indicates good management controls and attention, and that radiological protection pro-. grams are effective.

5. Lost-time accident rate is the number of worker injuries involving days away from work for every 200,000) man-hours worked.

6. Radioactive waste minimization requires management attention and good control over inany plant activities. 
The demonstration plant would most likely have an initial fuel load that consists of $2 / 3$-core slightly enriched uranium (SEU) fuel assemblies and 1/3-core MOX fuel asscmblies (based on past MOX fuel experience). A typical PWR requires $1 / 3$ of the core to be replaced with freshly reloaded fuel each time the reactor is refueled after the initial cycle of operation. A total of $557 \mathrm{~kg}$ of weapons plutonium would be denatured every year on the assumption of a 600 -MWe PWR operating at $80 \%$ availability. ${ }^{4} \mathrm{~A}$ reload batch of $19.1 \mathrm{MT}$ of MOX fuel per year would be required if refueling were done on an annual basis. Although plant economics typically favor a longer fuel cycle such as 18 months, the amount of fuel reloaded each cycle can be expressed in terms of an annual consumption rate. The discharge batch fuel from each cycle's refueling would be stored underwater in a spent fuel pool, until assembly decay heat became low enough to allow long-term dry storage of the fuel.

Because the behavior of MOX fuel in LWRs is similar to that of uranium fuels, there is no reason to expect that an ALWR, such as the AP-600, would behave differently if it wcre fueled with MOX fuel. Accordingly, PRA results ${ }^{5}$ for the AP-600 will not change significantly if MOX fuel were used in place of uranium fucl. The core melt probability (per reactor year) for the AP- 600 is estimated at less than 1 in 100,000 and the probability of a significant release (per year) is estimated at 1 in $10,000,000$. The dose due to such a release at the boundary of a typical commercial reactor site is estimated to be $1 \mathrm{rem}$. However, if the AP- 600 were located on a larger government-controlled site, the dose due to the release at the site boundary would most likely be smaller than $1 \mathrm{rem}$.

Table 3 suminarizes examples of the AP-600's design simplification relative to the Reference Westinghouse 2-loop design ${ }^{6}$ (e.g., Kewaunee, Nipot).

The several decades of LWR experience with plutonium fuel, and the more than 1200 operating years of U.S. LWR experience, indicate a mature technology that is highly feasible. Although the ALWR concept is relatively new, it incorporates state-of-the-art advances into the LWR technology base that has proven itself to be safe and efficient around the world. Each ALWR plant in the 600 -MWe range would use about $22,000 \mathrm{~kg}(=557 \mathrm{~kg} / \mathrm{yr}$ $\times 40 \mathrm{yr}$ ) of weapons-grade plutonium in fuel reloads, if the plant operated at an average availability of $80 \%$ during its 40-year expected life.

Tate 3. Design Simplification of an ALWR Compared to Existing Designs

\begin{tabular}{|c|c|c|}
\hline Equipment & Reference 2-loop & $\mathrm{AP}-600$ \\
\hline $\begin{array}{l}\text { Pumps - Safety } \\
\text { - Non-Safety }\end{array}$ & $\begin{array}{r}25 \\
188\end{array}$ & $\begin{array}{r}\text { None } \\
139\end{array}$ \\
\hline Pressurizer & $1,000 \mathrm{ft}^{3}$ & $1,300 \mathrm{ft}^{3}$ \\
\hline HVAC fans & 52 & 27 \\
\hline HVAC filter units & 16 & 7 \\
\hline $\begin{array}{r}\text { Valves }>2 \text { inch } \\
- \text { NSSS } \\
- \text { BOP }\end{array}$ & $\begin{array}{r}512 \\
2,041\end{array}$ & $\begin{array}{r}259 \\
1,530\end{array}$ \\
\hline $\begin{array}{c}\text { Pipe Length }>2 \text { inch } \\
- \text { NSSS } \\
\text { - BOP }\end{array}$ & $\begin{array}{l}44,300 \mathrm{ft} \\
97,000 \mathrm{ft}\end{array}$ & $\begin{array}{l}11,000 \mathrm{ft} \\
67,000 \mathrm{ft}\end{array}$ \\
\hline Evaporators & 2 & None \\
\hline $\begin{aligned} \text { Diesels - Safety } \\
\text { - Non-Safely }\end{aligned}$ & $\begin{array}{r}2 \\
\text { None }\end{array}$ & $\begin{array}{r}\text { None } \\
1\end{array}$ \\
\hline $\begin{array}{c}\text { Building Volume } \\
\text { - Containment } \\
\text { - Seismic }\end{array}$ & $\begin{array}{l}2.7 \times 10^{6} \mathrm{ft}^{3} \\
6.7 \times 10^{6} \mathrm{ft}^{3}\end{array}$ & $\begin{array}{l}3.4 \times 10^{6} \mathrm{ft}^{3} \\
1.7 \times 10^{6} \mathrm{ft}^{3}\end{array}$ \\
\hline
\end{tabular}




\section{Technical Availability}

Both the large-scale MOX fuel manufacturing process and the ALWR concept are based on technologies that have been in existence for several decades. The following discussion will present this point in further detail.

The MOX fuel manufacturing process is, to a large extent, similar to the process used to manufacture $\mathrm{UO}_{2}$ fuel for commercial power reactors. The extensive knowledge base acquired through 30 years of industrial manufacturing experience is directly applicable to MOX fuel fabrication except for the added consideration for plutonium radiological hazard. Plutonium metal is essentially an alpha emitter and can be handled without special shielding. However, the weapons-grade material and recycled fuel from LWRs (from which MOX has been produced in the past) have a buildup of americium, which emits high gamma radiation. Plutonium or its compounds in powcier can be handled in an enclosed system (e.g., gloveboxes) that confines the plutonium in welldefined areas and avoids contact by operating personnel. However, plutonium dust can build up on the interior surfaces, which, if not removed, results in gamma radiation from ste decay of plutonium-241 into americium-241.

While the above mentioned method of handling plutonium may have been acceptable in the past for smallscale MOX operations, remotely operated, automated fabrication facilitics are desirable for present and future larger scale operations. The mechanization of MOX facilities outside the U.S. has gradually led to production operations with minimum human contact or interven- tion. ${ }^{7-8}$ The remote automated process has allowed these facilities to meet safeguards and ALARA personnel protection requirements. This process also ensures improved special nuclear material accountability and control techniques. Combined with extensive U.S. fuel manufacturing experience, the technology can be used to design, construct, and operate a facility in this country.

In the past, MOX fuel fabrication has been regarded as a viable option. The following example illustrates the point. Westinghouse Electric Corporation applied for a license for a proposed mixed oxide fuel fabrication plant near Anderson, South Carolina in the 1970s. Because of extraneous factors, the plant was not built. However, the venture suggests that potential technical problems were regarded as soluble. The technical expertise needed for that license application could be used in constructing a new and modernized MOX facility.

Engineering designs for both the passive and evolutionary ALWRs are expected to receive final design approval by the U.S. Nuclear Regulatory Commission within the next few years.' The Final Design Approval will be followed by design certification and commercial venture, pending an order placed by utilities. Two of the evolutionary ALWRs, General Electric advanced boiling water reactors rated at $1350 \mathrm{MWe}$ apiece, have already received their construction permits from Japanese nuclear regulators, and are being built by Tokyo Electric Power Company..$^{10}$ The expected Final Design Approval and design certification of ALWR plants, combined with their ability to use MOX fuel, demonstrates their technical availability. 


\section{Economics}

Cost estimates are shown for a $60 \mathrm{MT} /$ year MOX facility. It would fuel approximately three of the 600 MWe ALWRs described above. Estimates for the facility, constructed on a government-owned site, were made using the Freiman Analysis of System Technique (FAST)." The FAST system is widely used to estimate DOE reconfiguration costs.

The facility would occupy a $150,000 \mathrm{ft}^{2}$ building that includes $25,000 \mathrm{ft}^{2}$ of office space. Manufacturing operations are $\mathrm{UO}_{2}$ and $\mathrm{PuO}_{2}$ powder conversion, pellet production, fuel assembly fabrication, and inspection and shipping. The facility includes parallel production lines for redundancy and the building is designed to expand if additional fuel fabrication capacity is required. A conservative cost of $\$ 682$ million was estimated for a fully automated "greenfield" MOX fuel fabrication facility. The greenfield estimate assumes that the facility would have to be constructed on an unimproved site (i.e., no existing infrastructure or support fa ilities). The estimate includes $\$ 102$ million for $\mathrm{UO}_{3}$ enleted uranium trioxide) to $\mathrm{UO}_{2}$ conversion, $\$ 205$ risiti in ior plutonium to $\mathrm{PuO}_{2}$ powder conversion, and $\$ 375$ million for MOX pellet production and fuel assembly fabrication.

Instead of constructing a new "greenfield" facility, an existing facility could be used. For example, the idled Allied General Nuclear Services (AGNS) separation plant in Barnwell, South Carolina, which meets or exceeds DOE/NRC design requirements for shipping, receiving, and storage, could be modified. The AGNS plant has a 100-acre processing facility, and the cost of converting this plant to a $60 \mathrm{MT} / \mathrm{year}$ MOX facility is estimated to be $\$ 262$ million. ${ }^{12}$ For one 600 -MWe ALWR demonstration plant, the required throughput for a MOX facility is about $19 \mathrm{MT} / \mathrm{ycar}$, as noted above. This assumes an $80 \%$ availability factor. Either of the above facilities could operate one shift per day and produce the required fuel at an annual operating cost of approximately $\$ 30$ million. ${ }^{12}$ If additional ALWRs were operated as part of an energy park concept, the same MOX facilities could produce $60 \mathrm{MT} / \mathrm{year}$, operating on three shifts per day at an annual operating cost of $\$ 60$ million. This quantity of MOX fuel would meet the annual requirements of three 600 -MWe ALWRs without requiring facility modifications.

Costs are available for at least one ALWR. ${ }^{13}$ The AP-600 has a gross electrical output of $630 \mathrm{MWe}$. Using a cost estimate of $\$ 1,765 / \mathrm{kWe}$ as noted below, the completed cost of a demonstration plant is expected to be $\$ 1,112$ million in 1990 dollars. Construction of the AP-600 is expected to take between 60 and 72 months once NRC design certification is received. Table 4 is a breakdown of the different cost elements.

Assuming a 35-MWe station service load for equipment essential to keeping the plant running, the net electrical output available for use locally or on the grid is 595 MWe. With an availability factor of $80 \%$, the demonstration plant would generate $4.17 \times 10^{6} \mathrm{MWh}$ of usable power per year of operation. This is based on $595 \mathrm{MWe}$ being generated during $80 \%$ of the 8,760 effective hours/year that the plant is expected to be on iine at full power. Because the average (including residential, industrial and commercial applications) U.S. end-use price paid for electricity is $6.69 \mathrm{k} / \mathrm{kWh}(\$ 66.90 / \mathrm{MWh})$, the annual output from this plant has a value approaching $\$ 280$ million in 1990 dollars. ${ }^{2}$ If the entire plant output of 595 MWe were sold on the grid, the prevailing bulk power sales rate might be in the range of $\$ 52.50 / \mathrm{MWh}$. Reference 14 shows fixed O\&M costs of $\$ 60 / \mathrm{kWe}$ per year and variable $O \& M$ costs of 6 mills/kWh. Based on the plant generating $4.17 \times 10^{6}$ of usable power per year, these O\&M costs convert to $\$ 61$ million per year.

\begin{tabular}{|lr|}
\hline Table 4. Costs in $\mathbf{1 9 9 0}$ \$/kWe \\
Vendor's Overnight Cost* & 1,370 \\
Owner's Cost & 156 \\
First-Of-A-Kind Engincering & 41 \\
Interest During Construction & 198 \\
& \\
Total 1990 \$/kWe Completed Cost & 1,765 \\
(*Based on plant being built "overnight"; includes contingencies but assumes no significant time delay in \\
\hline
\end{tabular}


These values have been developed specifically for the AP-600 design plant. Other passi design plants, such as the SBWR, should be in this general range of financial values. Table 5 summarizes the above information for a single AP-600. It includes similar information for twin AP-600s, as well as a $1200-M W e$ evolutionary plant.

Mixed-oxide fuel discharged from ALWR operation for disposal without reprocessing would be managed using procedures analogous to those for commercial reactor fuels. The fuel assemblies would be stored underwater in the reactor spent fuel pool for a time necessary to allow cooling to acceptable heat outputs. The assemblies would then be placed into dry storage pending shipment to a national waste repository. Because no provision has been made for disposal of MOX fuel in the first repository, dry storage would have to be provided for the entire 40-year output of spent fuel. This amounts to about 1400 assemblies per 600 -MWe reactor.
It is assumed that the disposal of MOX fuel in a repository would be handled in the same way as normal LWR fuel with an approximate $\$ 50$ million additional cost for the qualification of the MOX fuel. Based on the current repository disposal cost assessment of $\$ 500,000$ per package (about 4 assemblies per package), the annual disposal cost would be $\$ 4$ million per $600 \mathrm{MWe}$ reactor. A more detailed description of spent fuel disposal is given in Reference 4.

Converting all costs to 1992 dollars and summing yields the following costs, the initial capital costs would be in the range of $\$ 1.5$ to $\$ 2$ billion for the demonstration system and $\$ 4$ to $\$ 4.5$ billion for a three-reactor system, depending on the MOX fabrication option chosen. Annual operating costs would be about $\$ 110$ million for the demonstration case and $\$ 250$ million for the three-reactor case. The value of electricity produced would be about $\$ 300$ million and $\$ 900$ million per year, respectively. While the exact result would depend on cost-benefit discount levels and future electricity sales rates, it is likely that this mode of operation would at least break even financially over the life of the project.

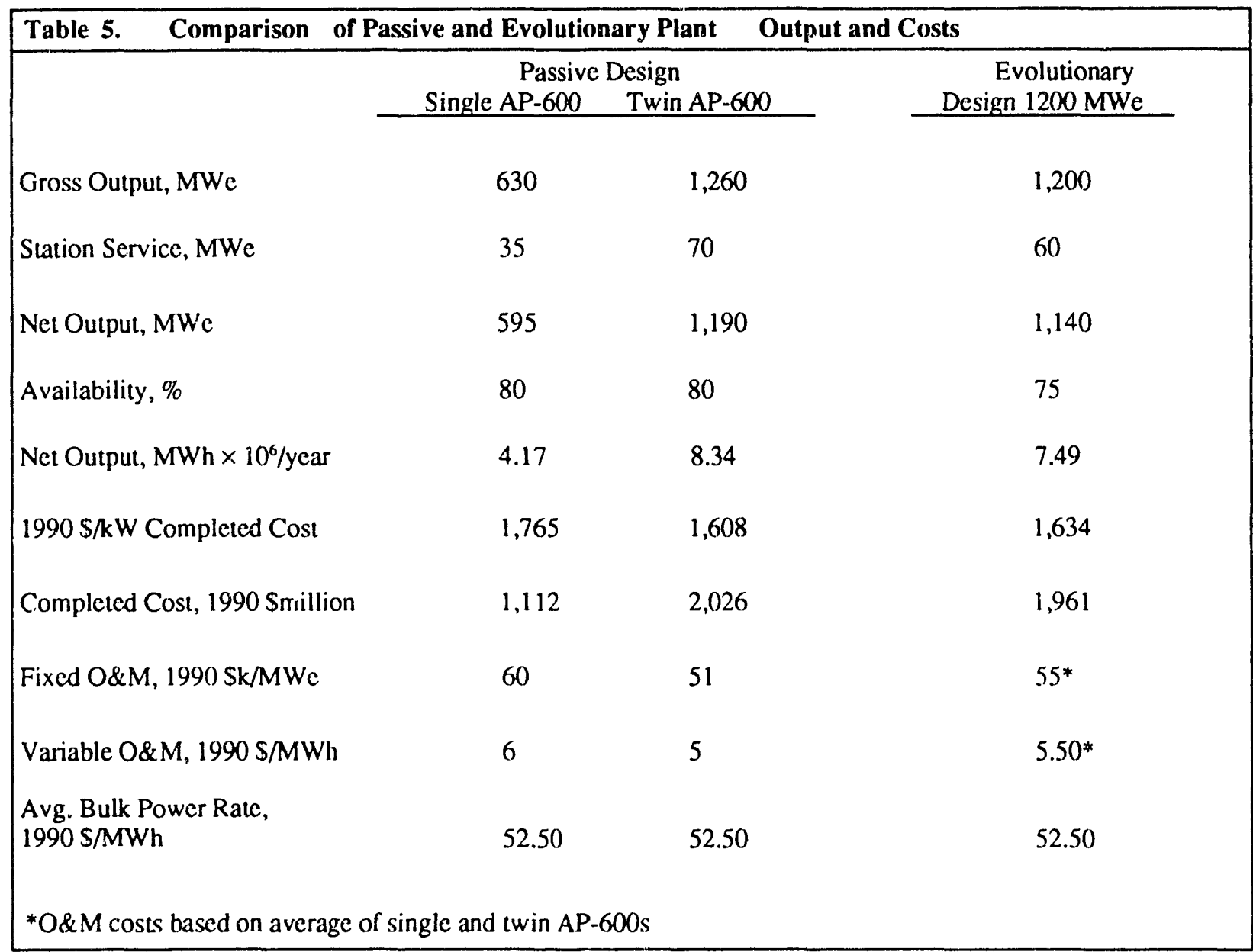




\section{Regulatory Issues}

fiv system for plutonium denaturing must mcet a wide varicty of regulatory issues and criteria. In the following, points applicable to the ALWR concept are listed first. Some of the wide variety of regulations applicable to most plutonium denaturing systems are listed second.

\section{1 - Aspects Applicable to ALWR}

(1) The ALWR has an extensive history of planning and detailed enginecring. The conceptual design of the Westinghouse AP-600 was completed in 1989 and gained funding for detailed design as part of the Electric Fower Research Institute/DOE advanced light water reactor program. ${ }^{\text {is }}$ By November 1991, about 700,000 man-hours of engineering had been accumulated, more than any othe system mentioned in this document.

(2) The ALWR design has already earned commendation from DOE officials in terms of potential regulation. As William Your 's, Gssistant Secretary for Nuclear Energy, has stated, ${ }^{16}$

"The safer and more efficient advanced-design nuclear engineering plants, which are now bcing developed, will be an important part of a revitalization of the nuclear option. The design being developed by Westinghouse [the AP-600] will not only build on the extensive experience base from threc decades of light water reactor operations, but will also take advantage of simplifications and innovations in design and construction that are unique to this reactor's smaller power rating."

(3) The ALWR will have a standardized design, a goal that has been acknowledged by industry leaders to be wital to future orders. As Ivan Selin, Chairnan of the U.S. Nuclear Regulatory Commission, noted in November 1991, ${ }^{17}$

"We all recognize that standardization will be a key element to reviving nuclear power. In the NRCs view, standardized design will also enhance plant safety."

The process of standardization was begun by the NRC in 1989, and is codified in 10 CFR 52.

Designers of the Westinghouse AP-6(6)0 ALWR will provide, or have produced, six documents lcading to a design certification by January 1995. 15 The Standardized Safety
Analysis Report (SSAR), scheduled for completion in June 1992, covers the safety aspects of the nuclear steam supply system, along with balance-of-plant fcatures with safety impact. The inspections, tests, analysis, and acceptance criteria will show that the plant conforms to the certified design. The Probabilistic Risk Assessment, scheduled completion date of June 1992, determines the risk to the public. The Safety Evaluation Report (SER), scheduled for completion in February 1993, is a report of the review of the $S ?$ ? by NRC staff and by the Advisory Committec on Reactor Safcguards. Final Design Approval by the NRC is the last step befere design certification. Safety Evaluation Report and Final Design Approval are scheduled for November 1994. Design Certification, scheduled for completion in May 1995, is a rulemaking proces ding to certification as a standardized plant.

(4) Approval by the NRC of any new or modified reactor design must be based on close interaction with NRC staff. The AP-60) ALWR qualifics handsomcly in this respect. In March 1992, for example, a joint test program with the NRC was established to study ALWR performance. A key test will be the FHFP IST - the fullheight, full-pressure integral systems test. Designers have already proposed to the NRC to perform this test in Italy and other tests in Oregon. A Certification Program Summary, covering major technical issues, was submitted by ALWR personncl to NRC staff in the fall of 1991.

\section{II - General Aspects of Regulation}

A wide varicty of regulations from both fedcral and state agencics are applicable to this project. The following is only a brief sampling, within the space limitations imposed in this document.

Sitc Criteria: The site shall meet site critcria as described in 10 CFR Part 100, especially Part 100.11. This requires an cxclusion arca such that a postulated fission relcase to any individual on the site's boundary produces a whole body radiation dose within two hours less than $25 \mathrm{rcm}$, or a total radiation dose less than $300 \mathrm{rcm}$ to the thyroid from iodine exposure.

Accidental Radioactivity Releases: The facility shall be designed such that, after a design basis accident, potential exposure to radiation shall be within applicable guidelines of DOE Or $\lrcorner$ er 5480.6 , and the General Design Criteria of 10 CFR 50, Appendix A. Additional safety requirements will be as specified in 10 CFR 50.34(I), "Additional TMI-Related Requirements".

Occupational Exposure: Design shall insure that worker radiation exposure during normal operations and antici- 
pated operational occurrences shall not exceed DOE guidelines established in DOE Order 5480.11 and applicable sections of 10 CFR.

Environmental Protection: The design shall meet relevant DOE Orders, such as 5484.1, "Environmental Protection, Safety and Health Protection Information Raporting Requirements".

JEFA: All facilities shall be designed, constructed, and operated in full compliance with the letter and spirit of the National Environmental Protection Act, including specific environmental mitigation commitments.

Safety and Sicurity: The facilities shall have safety and security systems in conformance with DOE Orders 5633.3, $:$ nd the 5632 se:ies, which require that safety and security systems have a demonstrated level of performance.

Right-to-Know: The project shall comply with the Emergency Planning and Community Right-to-Know Act of 1986 (42 USC 11001-11050) in terms of notification, inventory reporting, material safety data sheets, and annual reporting requirements.

Opcrator Training: DOE Order 5480.6, "Safety of DOE Owned Nuclear Reactors", Scction 8e, requires that Amcrican Nuclear Socicty Standard 3.1, "Selection, Qualification and Training of Personnel for Nuclear
Power Plants", October 1980, be the basis for qualifications and training requirements for reactor personnel.

Reactor Simulator: The facility shall have a simulator and associated support facilitics and services, as prescribed in American National Standard, "Nuclear Power Plant Simulators for Use in Operator Training," ANSI/ANS-3.5.

Communications: The facility shall have a telecommunications system design that complies with DOE Order $6430.1 \mathrm{~A}$.

Classification: Plant structures, systems and components shall be classified according to recognized schemes, including Safety Class (ANSI/ANS-51.1-1983) and Electrical Class (IEEE 308-1980).

Design and Description Documents: The project shall prepare a Plant Design Requirements Document, an Overall Plant Design Description and System Design Descriptions, in accordance with DCE Standard NE F1-2T.

Decontamination and Decommissioning: The complex shall be designed to facilitate decontamination and eventual decommissioning as required by DOE Orders 5820.2A and 6430.1A and applicable federal and state requirements. 


\section{Political and Public Acceptance}

A number of reasons exist a o why plutonium disposition, as described in this and other sections, will be politically and publicly acceptable. In the following, the first part deals more specifically with the ALWR option and the Savannah River Site; the second part deals with public acceptance in general.

\section{I - Aspects Applicable to ALWR}

(1) The option would reduce the risk of proliferation, as described elsewhere. As the Cold War ends, proliferation concerns have come to tise fore. It seems logical that these concerns can be met best in a highly safeguarded arca. SRS has had decades of experience with national security questions, and no significant breaches of security have occurred here in that time. Plutonium is known to the public to be the ingredient of nuclear weapons, and it would be safer here at the Savannah River Site, as its cnergy was slowly converted to electricity, as anywhere in the Nation.

(2) Support for the nuclear industry in the Central Savannah River Area is strong, compared to many other DOE sitcs. The governor and members of Congress from South Carolina have long been strong supporters of SRS and its activitics. If it could be demonstrated that a useful product, electricity, would resuit from the process, that tradition of support would continue.

(3) The key point to be made is that a substance, which could be regarded as Cold War waste, is now being converted to a useful product, electricity.

There is little or no public acceptance, anywhere in this Nation, of waste per se. Many examples abound. The problems in obtaining public acceptance of the proposed nuclear waste repository in Nevada have been legion. Not long ago, the governor of Idaho, Cecil Andrus, refused to allow wastes from the Rocky Flats Plant into his state, although they would be shipped from one DOE facility to another. The governor of South Carolina, Carroll Campbell, expressed serious concern to Secretary Watkins when stories about the possible shipment of plutonium pits to SRS, without further processing or production of a useful product, were discussed in the press. The governor of Georgia, Zell Miller, expressed outright opposition to the scheme, even though none of the matcrial would be stored in his state.
The reason why wastes are not acceptable, yet a process that uses waste would be, has been described by academics such as Roger Kasperson of Clark University. ${ }^{18}$ The wastes produce nothing of value; if electricity can be produced from them, they will be publicly acceptable.

(4) The ALWR proposal does not require the public to accept a radically different reactor type. It is an evolution of present systems, rather than a completely new concept. The maj, $T$ difference is that public safety will be increased, and this can be demonstrated quantitatively. The fact that over 1000 reactor-years of experience have already been accumulated will serve to reassure the public that their safety is paramount.

(5) Another aspect of the proposal that would improve DOE's position with respect to Congress is the financial side. At present, DOE is viewed by some in Congress as almost exclusively spenders, not much interested in earning its way. As noted elsewhere in this section, the ALWR option will allow electricity to be generated, with associated revenues accruing to DOE. With this option, DOE could advise Congress, "Revenues are being accrued, not merely dispensed". It is certain that the reaction from Congress and the public to this would be favorable.

\section{II - General Aspects of Public Acceptance}

(1) If the term "ultimate recycling" is used to describe the process, the title alone will bring considerable acceptance. Recycling is a word with considerable public approval. The public will understand that, while recycling of aluminum cans produces some small benefit, recycling of plutonium will produce vastly more.

(2) The plutonium disposition process can be described as the final and culminating act of the Cold War, thus yielding more public acceptance. There has been strong public support for decades to reduce arms levels. What would be done with the arms and their components when these reductions were achieved was left to another day. That day has come, and the plutonium disposition system outlined here would solve the problem that was postponed for decades. This aspect alone would generate considerable political support.

(3) Civilian nuclear power has not enjoyed strong public support in mariy years. No reactor order since 1974, 19 years, has been completed. While the industry is interested in developing new reactor types, there is little public support for this activity. Some funding has been 
allocated by Congress towards this end, but it is unclear when new and improved models will actually be built.

Ultimate recycling offers a solution to this problem, one that would gain public acceptance. Because plutonium would be denatured by means of an advanced reactor, there would be more support than if the Secretary of Encrgy merely asked Congress for funds to assist the nuclcar industry in gencral. The new reactor would solve what had been thought to be an insoluble problem.

(4) For many obscrvers, DOE has frequently scemed to be a reactive organization, dealing with problems only as they were reported in the media. This assessment may not be fair, but it is often held.

The ultimate recycling option would demonstrate to the public and its elected representatives that DOE was looking forward and solving a problem that had seemed impossible for decades. There would undoubtedly be accolades for DOE as this fact was shown to the public.

(5) There is already precedence for the project, and precedence always suggests public acceptance. The Wall Street.Journal, in a front-page article of September 1, and the New York Times ("Russia to Sell U.S. Uranium from Scrapped Atomic Arms": September 1, 1992, p. A5) ${ }^{19}$ noted that Russia will $i$, he U.S. tons of highly-enriched uranium from its scripped nuclear arms. The story was repeated in other national media. The Administration said the U.S. would dilute the matcrial for use as commercial reactor fucl. The action marks the first transfer between the arms program and commercia! nuclear power since the end of the Cold War.

\section{References}

1. H. Bairiot and C. Vandenburg. Use of MOX Fuels, Nuclear Fuel Cycle in the 1990s and Beyond the Century: Some Trends and Foresecable Problems, Tcchnical Report Scrics No. 305, International Atomic Encrgy Agency, Vienna, Austria, 1989.

2. Encrgy Information Administration. Anmual Energy Outlook 1992, Washington, DC, 1992, Table A-4.

3. Performance Indicators for the U.S. Nuclear Industry, The Nuclear Professional $\underline{6}$ (2), Spring 1991.

4. M. R. Buckncr ct al., Strategies for Denaturing the Weapons-Grade Plutonium Stockpile, WSRCRP-92-1004, Aiken, SC, October 1992, p. 3-1. The calculations in this document refer to an aver- age availability of $75 \%$. Values have been adjusted for $80 \%$ availability, on the basis of the estimates in this section. Readers can re-calculate values for different assumed availabilities. Note that some plutonium would remain in the fuel rods after denaturing; see W. E. Graves, Plutonium Reload Requirements for the PFBR, Savannah River Technology Center, Aiken, SC, May 21, 1992. The exact proportion of plutonium remaining after denaturing would depend on many factors.

5. Westinghouse Electric Corporation. Westinghouse and the AP-600, Pittsburgh, PA, 1989.

6. "Advanced Reactor Design, Turning the Kcy," Nuclear Engineering International, November 1991.

7. “PNC's Fully Automated MOX Plant Starts Opcration," Nuclear Enginecring International 33, (403) $18,1988$.

8. "Sicmens Says Russian Copy of SBH Could be Built in Three Years," Nuclear Fuel, June 22, 1992.

9. Inside N.R.C. May 4, 1992, and June 29, 1992.

10. The Energy Daily, June 4, 1992.

11. Ref. 4, Buckner et al., op. cit., p. 4-3.

12. Ref. 4, Buckner et al., op. cit., p. 4-5.

13. Westinghouse Electric Corporation. The Westinghouse AP-600, Pittsburgh, PA, Revised 1991.

14. U.S. Council for Encrgy Awarencss. Advanced Design Nuclear Power Plants: Competitive, Economical Electricity, Washington, DC, Junc 1992.

15. H. Bruschi and T. Andersen. "Turning the Key," Nuclear Engineering International, November 1991.

16. W. H. Young, Assistant Secretary of Nuclear Energy, Department of Encrgy, memorandum "Initial Mecting of the Plutonium Disposition Task Force Working Group," Washington, DC, August 10, 1992.

17. Ivan Selin, Speceh presented to the Winter Mecting of the Amcrican Nuclear Socicty, San Francisco, CA, November 1991, page 1.

18. Personal Communication with Roger Kasperson, Clark University, Worchester, MA, December 1992.

19. "Russia to See U. S. Uranium from Scrapped Atomic Arms," New York Times, September 1, 1002, page A5. 

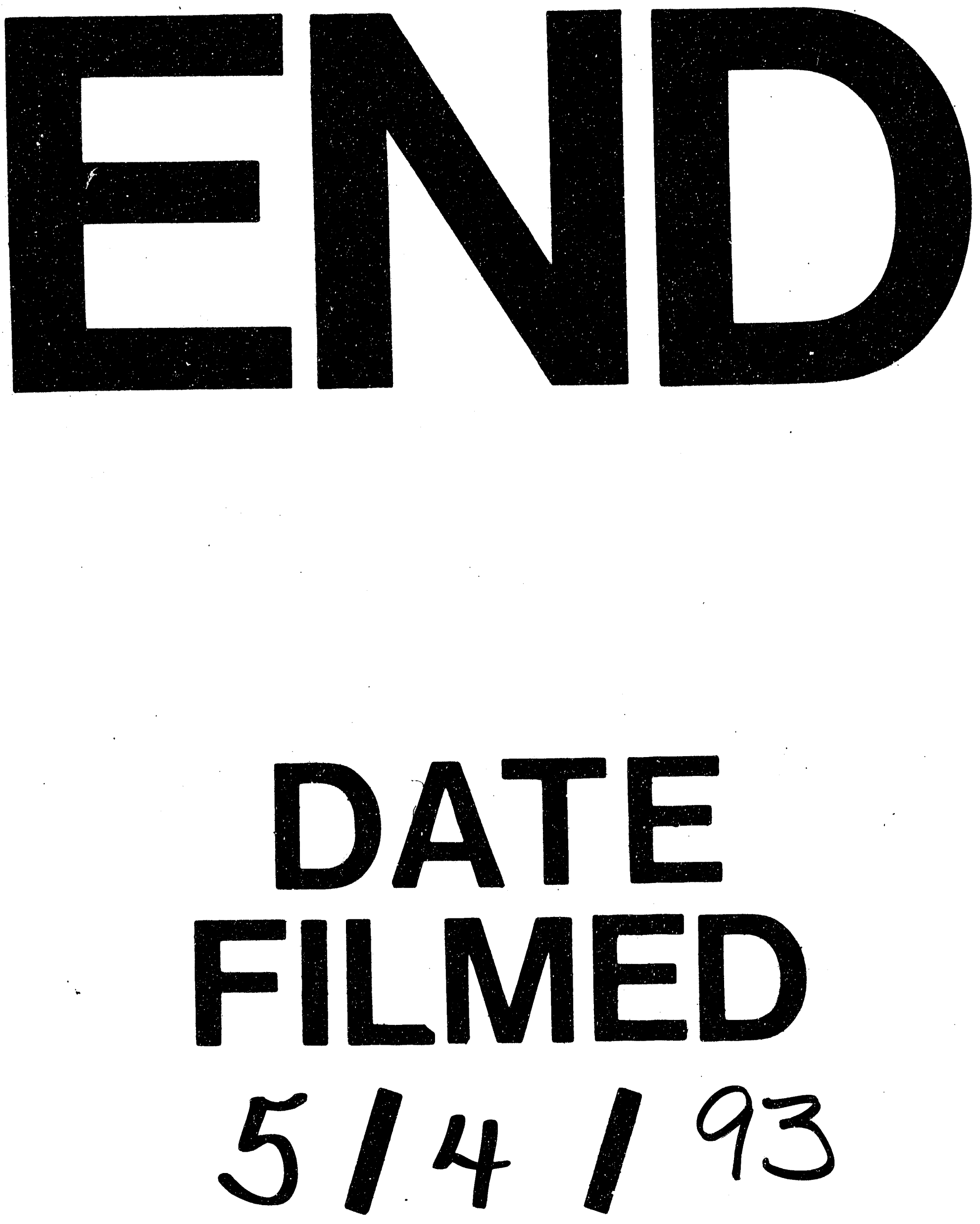
